\title{
The implication of ocular manifestation of COVID-19 for medical staff and patients - systematic review
}

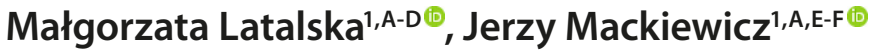 \\ ${ }^{1}$ Department of Vitreoretinal Surgery, Medical University, Lublin, Poland \\ A - Research concept and design, B - Collection and/or assembly of data, C - Data analysis and interpretation, \\ $D$ - Writing the article, E-Critical revision of the article, F- Final approval of article
}

Latalska M, Mackiewicz J. The implication of ocular manifestation of COVID-19 for medical staff and patients - a systematic review. Ann Agric Environ Med. 2020; 27(2): 165-170. doi: 10.26444/aaem/122790

\begin{abstract}
Introduction. SARS-CoV-2 (severe acute respiratory syndrome-coronavirus-2) is a coronavirus that causes COVID-19 (coronavirus disease 2019) with mild to severe respiratory illness. It is a highly contagious disease transmitted through direct or indirect contact with infected people or contaminated surfaces, mainly through respiratory droplets, but other routes are being investigated.

Objective. It is known that coronaviruses (CoVs) can cause a variety of ocular pathologies in animals, including conjunctivitis, anterior uveitis, retinitis, and optic neuritis, many of which are severe. However, there is no evidence of the SARS-CoV-2 presence in the eye tissue of asymptomatic patients, even if the symptomatic incidence is low. This systematic review presents updated literature on this issue.

Abbreviated description of the state of knowledge. COVID-19 has now spread throughout the continents and poses a global threat to public health. The risk of rapidly overloading health care systems and causing substantial mortality worldwide is real. On 11 March 2020, the World Health Organization (WHO) announced coronavirus as a global pandemic. Several studies described a few cases with initial ocular symptoms followed by systemic symptoms of the disease.

Summary. Although the frequency of transmission of SARS-CoV-2 infection through the eye is low, ocular symptoms are not uncommon in COVID-19. In some cases, eye symptoms may be the first signs of illness. This implies the need for hygienic recommendations and use of personal protective equipment (PPE) for medical staff and other services to minimize COVID-19 infection of both health-care workers and patients. A triage for ophthalmic outpatient clinic is mandatory.
\end{abstract}

Key words

Ocular manifestation, conjunctivitis, SARS-CoV-2, COVID-19, conjunctival swab, tears sample.

\section{INTRODUCTION}

SARS-CoV-2 (severe acute respiratory syndromecoronavirus-2) is a coronavirus that causes COVID-19 (coronavirus disease 2019) with mild to severe respiratory illness. It is a highly contagious disease transmitted through both direct and indirect contact with infected people or contaminated surfaces, mainly through respiratory droplets, but other routes are being investigated. Symptoms such as fever, cough and shortness of breath can appear 2 - 14 days after exposition. People with severe infections can develop pneumonia and die from acute respiratory failure $[1,2]$. On 11 March 2020, the World Health Organization (WHO) announced the coronavirus as a global pandemic, covering both rural and urban areas. The Covid-19 pandemic has led to global restrictions in: inter-national travel, public transport, trade in both agricultural and manufactured goods, employment in every sector of the economy, social and public life.

SARS-CoV-2 is one of seven coronavirus species which are known to cause diseases in humans and is the largest RNA virus. The viral particle contains single-stranded RNA composed of approximately 30,000 nucleotides. Its diameter

Address for correspondence: Małgorzata Latalska, Department of Vitreoretinal Surgery, Medical University, Lublin, Poland

E-mail: mlatalska@o2.pl

Received: 03.05.2020; accepted: 24.05.2020; first published: 05.06.2020 is aproximately $60-140 \mathrm{~nm}[3,4]$. The mutation rates of RNA viruses are greater than DNA mutation rates. Currently, two types of SARS-CoV-2 have been detected [5]. The L form, likely more aggressive, is suspected to be a derived variant of the ancestral $S$ type $[5,6,7]$. The $L$ form was initially significantly more prevalent in Wuhan, China, than other places [5]. SARS-CoV-2 like SARS-CoV (severe acute respiratory syndrome coronavirus) and MERS-CoV (Middle East respiratory syndrome coronavirus), belongs to the $\beta-\mathrm{CoV}$ family and can cause fatal pneumonia. SARS-CoV-2 has a lower disease severity, but higher transmission efficiency [8]. The characteristic of Covs is presented in Table 1.

\section{OBJECTIVE}

It is known that coronaviruses (CoVs) can cause a variety of ocular pathologies in animals, including conjunctivitis, anterior uveitis, retinitis, and optic neuritis, many of which are severe [9]. However, there is no evidence of the SARS-CoV-2 incidence in the tears or conjunctival tissue of asymptomatic patients. Even in those with confirmed disease the presence of SARS-CoV-2 on the ocular surface is low $[10,11,12]$. Therefore, against common beliefs, the possible transmission of SARS-CoV-2 by conjunctiva is controversial.

This systematic review presents updated literature on this issue. A search was conducted of PubMed, Google Scholar, 
Table 1. Characteristics of Coronaviruses $[8,14]$

\begin{tabular}{|c|c|c|c|c|c|c|}
\hline $\begin{array}{l}\text { Type of } \\
\text { Cov }\end{array}$ & $\begin{array}{l}\text { Year of } \\
\text { isolation }\end{array}$ & $\begin{array}{c}\text { Incubation } \\
\text { period }\end{array}$ & $\begin{array}{l}\text { Clinical } \\
\text { features }\end{array}$ & Infectivity & $\begin{array}{c}\text { Fatality } \\
\text { rate }\end{array}$ & $\begin{array}{c}\text { Animal } \\
\text { Source } \\
\text { (natural } \\
\text { reservoir= } \\
\text { bats) }\end{array}$ \\
\hline $\begin{array}{l}\text { SARS- } \\
\text { Cov }\end{array}$ & 2003 & 2-14 days & $\begin{array}{c}\text { Flu-like } \\
\text { Pneumonia, } \\
\text { kidney } \\
\text { failure }\end{array}$ & High & $9.6 \%$ & cats \\
\hline $\begin{array}{l}\text { MERS- } \\
\text { Cov }\end{array}$ & 2012 & 2-14 days & $\begin{array}{l}\text { Flu-like } \\
\text { Pneumonia, } \\
\text { kidney } \\
\text { failure }\end{array}$ & Low & $34.5 \%$ & $\begin{array}{c}\text { dromedary } \\
\text { camel }\end{array}$ \\
\hline $\begin{array}{l}\text { SARS- } \\
\text { Cov-2 }\end{array}$ & 2019 & 2-14 days & $\begin{array}{c}\text { Flu-like } \\
\text { Pneumonia }\end{array}$ & Highest & $\begin{array}{c}3.7 \% \\
\text { until } 12 \\
\text { March }\end{array}$ & pangolin \\
\hline
\end{tabular}

and Scopus for papers related to ocular manifestation and SARS-CoV-2/COVID-19, published up until 28 April 2020, using appropriate keywords: “2019-nCov", 2019 "novel corona virus", COVID-19, corona virus disease-2019, SARSCov-2 and "Ocular", "Ophthalmic", ophthal* "conjunctiva*", conjunctivitis, eye, tears. Studies published in the English language entire research or abstracts available in English) were included from inception to 28 April 2020. Studies reporting ocular manifestation of COVID-19 patients were included. 12 studies were identified: observational and case reports, case series, and any other types of study design which reported ocular manifestation or its complication of SARSCOV-2 infection. However, more articles discussing ocular symptoms and SARS-Cov-2 transmission through tears or conjunctival secretion are also available, based on studies announced by other researchers and consider extensively anti-infection measures.

\section{DESCRIPTION OF THE STATE OF KNOWLEDGE}

A recent report suggests that SARS-CoV-2 could betransmitted via asymptomatic infected individuals and carriers who never develop symptoms of COVID-19, but nevertheless can be a source of contagion $[13,14]$. Transmission can occur during the incubation period. Despite the suggestion that CoVs to be transmited by aerosol contact with the conjunctiva in patients with active disease, the frequency of conjunctivitis in patients with COVID-19 reported to- date is low $-<3 \%[10$, 12, 15-18]. Furthermore, SARS-Cov-2 was also found in an RT-PCR test in conjunctival samples in patients COVID-19 positive, but without symptoms of conjunctivitis $[19,20]$. CoVs can also be transmitted by contact with a contaminated surface and then touching the mouth, nose or eyes [7,21,22]. SARS-CoV-2 can remain on hard plastic surfaces for hours or even days [23-26].

However, Sun et al concluded that the eye is rarely involved in human CoVs infection and is not a preferred portal for spreading the infection to the respiratory tract [27]. On the other hand, the SARS-CoV-2 RNA has been found in conjunctival scrape samples in a small number of COVID-19-positive patients with conjunctivitis [10, 28]. Furthermore, the occurrence of conjunctivitis prior to pneumonia in several infected patients may suggest the potential ocular route of SARS-CoV-2 transmission $[20,28$, $29,30]$.
Theoretically, the ocular surface is an open microenvironment, and the conjunctiva can be infected directly by an aerosol droplet from an infected patient or secondary to viral spread from the upper respiratory tract through nasolacrimal duct or via haematogenous spread $[9,31]$. Futhermore, the mucosa of the conjunctiva and upper respiratory tract share the same entry receptor of SARS-CoV-2 on host cell membranes- angiotensin-converting enzyme 2 (ACE2) $[20,32$, 33]. Expression of the ACE receptor has been demonstrated in retinal pigment epithelium (RPE), choroid and neural retina and sclera [34]. Immuno-histo- chemistry (IHC) studies have shown localization of ACE and Ang-II in the non-pigmented epithelium of the ciliary body, corneal epithelium and endothelium, conjunctival epithelium and trabecular meshwork lining. In the posterior segment, ACE and Ang-II were found in retinal ganglion cells, some cells in the inner nuclear layer and retinal photoreceptor cells, endothelium lining of choroidal and retinal vessels [35]. ACE2 receptor was also located in the aqueous humour [36]. A recent study reported a novel route of SARS-CoV entry to human host cells - through its interactions with CD147 [32]. The presence of CD147 in tears, the corneal epithelium and endothelium, stromal keratocytes, conjunctiva and retinal pigment epithelium has already been confirmed [37]. On the other hand, the tear film has antiviral properties and would inactivate viruses, for example, by the protein lactoferrin, which likely prohibits adenovirus entry into corneal epithelial cells [38-40].

\section{DISCUSSION}

According to updated literature, up until 28 April 2020, red eye and conjunctivitis were noted in 108 cases out of 1,882 COVID-19 positive patients (5.74\%) (Tab. 2). Conjunctival or tear sample RT-PCR assay for SARS-CoV-2 was positive in 9 cases out of 999 reported, examined COVID-19 positive or suspected patients (0.9\%) (Tab. 2).

It may seem that SARS-CoV-2 is rarely detected in the conjunctival sac. However, several conditions can implay these results. Firstly, SARS-CoV-2 might not exist at all in the conjunctival sac or tear fluid at the stage of disease when the sample was taken. Secondly, the sensitivity of current RT-PCR test for SARS-CoV-2 RNA is insufficient, generally ranging from $50 \%-60 \%$, despite nasopharyngeal swab being set as the gold standard for laboratory confirmation of COVID-19 pneumonia [39]. Therefore, negative results may be false negative, and the presence of the virus cannot be ruled out. Finally, the virus may be present in the conjunctival sac or tears only for a very short period of time. According to Colavita et al., SARS-Cov-2 may present in tears and conjunctival secretions only in the early phase of infection [41]. Furthermore, it is possible that many false positive or negative results, can be caused by sample contamination and damage to genetic material [42].

Further studies are needed to determine whether the SARS-CoV-2 virus has the potential to transmit from personto-person through the conjunctival route. Recording all COVID-19 symptoms, including ocular symptoms, which are sometimes very discreet and overlooked in the face of more serious general complications, can be helpful in this assessment. Performing tear or conjunctival tests in all COVID-19 suspected patients during the pandemic era 
Table 2. Studies reporting conjunctival involvement in patients with SARS-CoV-2 Infection

\begin{tabular}{|c|c|c|c|c|c|c|}
\hline Author & Type of study/site & $\begin{array}{l}\text { Chronic medical } \\
\text { history }\end{array}$ & $\begin{array}{l}\text { Patients ( } \mathrm{n}) \\
\text { (mean age) }\end{array}$ & Ocular manifestation & $\begin{array}{l}\text { Relation to } \\
\text { systemic } \\
\text { symptoms }\end{array}$ & $\begin{array}{l}\text { RT- PCR in } \\
\text { conjunctival } \\
\text { samples }\end{array}$ \\
\hline $\begin{array}{l}\text { Guan et al. } \\
2020 \\
{[12]}\end{array}$ & China & $\begin{array}{c}\text { Hypertension } n=165 \\
\text { DM } n=81 \\
\text { CHD } n=27 \\
\text { Hepatitis } B=23 \\
\text { Cerebrovascular disease } n=15 \\
\text { COPD } n=12 \\
\text { Cancer } n=10 \\
\text { Chronic renal disease } n=8 \\
\text { Immunodeficiency } n=2\end{array}$ & $\begin{array}{c}\mathrm{n}=1,099 \text { positive } \\
\text { (median age } 47 \mathrm{yrs} \text { ) }\end{array}$ & Conjunctivitis $n=9$ & N.A. & N.A. \\
\hline $\begin{array}{l}\text { Zhou et al, } \\
2020 \\
{[20]}\end{array}$ & $\begin{array}{c}\text { Retrospective } \\
\text { cohort } \\
\text { study, } \\
\text { Wuhan } \\
\text { China }\end{array}$ & N.A. & $\begin{array}{c}n=63 \text { positive } \\
n=4 \text { suspected } \\
\text { (mean age } 35.7 y r s \text { ) }\end{array}$ & $\begin{array}{c}\text { Conjunctivitis } n=1 \\
\text { with negative conjunctival } \\
\text { sac } 2019-\mathrm{nCoV} \text { test }\end{array}$ & $\begin{array}{l}\text { first } \\
\text { to COVID-19 } \\
n=1\end{array}$ & $\begin{array}{c}\mathrm{n}=3 \text { positive } \\
\text { without ocular } \\
\text { symptoms }\end{array}$ \\
\hline
\end{tabular}

\begin{tabular}{|c|c|c|c|c|c|c|}
\hline $\begin{array}{l}\text { Xu et al. } \\
2020 \\
{[43]}\end{array}$ & $\begin{array}{l}\text { Cross-sectional non- } \\
\text { randomized study, } \\
\text { Shenyang } \\
\text { China }\end{array}$ & $\begin{array}{l}\text { DM } n=3 \text {, } \\
\text { Hypertension } n=4 \text {, } \\
\text { Hepatitis } B n=1\end{array}$ & $\begin{array}{l}n=14 \text { COVID-19 } \\
n=16 \text { suspected } \\
\text { (mean age } 48 y r s \text { ) }\end{array}$ & No ocular symptoms & N.A. & $\begin{array}{l}\text { no positive } \\
\text { samples }\end{array}$ \\
\hline $\begin{array}{l}\text { Zhang et al, } \\
2020 \\
{[47]}\end{array}$ & $\begin{array}{c}\text { Cross- sectional study, } \\
\text { Wuhan } \\
\text { China }\end{array}$ & N.A. & $\begin{array}{c}\mathrm{n}=102 \text { suspected } \\
\mathrm{n}=72 \text { positive } \\
\text { (mean age } 57.63 \mathrm{yrs} \text { ) }\end{array}$ & Conjunctivitis n=2 (2.78\%) & N.A. & $\begin{array}{l}\mathrm{n}=1 \text { positive } \\
\text { with conjunctivitis } \\
\text { (in ocular } \\
\text { discharge) }\end{array}$ \\
\hline $\begin{array}{l}\text { Deng et al, } \\
2020 \\
{[48]}\end{array}$ & $\begin{array}{c}\text { Observation al study, } \\
\text { Wuhan } \\
\text { China }\end{array}$ & $\begin{array}{c}\text { Cardiovascular and } \\
\text { cerebrovascular diseases } \\
n=46(40 \%) \\
\text { Endocrine system disease } \\
n=19(17 \%)\end{array}$ & $\begin{array}{c}\mathrm{n}=114 \\
\text { NCP positive } \\
\text { (mean age 61.4yrs) }\end{array}$ & No ocular manifestation & N.A. & $\begin{array}{l}\text { no positive } \\
\text { samples }\end{array}$ \\
\hline $\begin{array}{l}\text { Wu et al. } \\
2020 \\
{[30]}\end{array}$ & $\begin{array}{c}\text { Case series study, } \\
\text { Yichang } \\
\text { China }\end{array}$ & & $\begin{array}{c}\mathrm{n}=38 \text { suspected } \\
\mathrm{n}=28 \text { positive } \\
\text { (mean age } 65.8 \mathrm{yrs} \text { ) }\end{array}$ & $\begin{array}{c}\text { Conjunctivitis } \\
n=12 \\
\text { hyperaemia } n=3 \text {, chemosis } \\
n=8 \text {, epiphora } n=7 \\
\text { secretion } n=7\end{array}$ & $\begin{array}{c}\text { first to } \\
\text { COVID-19 } \\
n=1\end{array}$ & $n=2$ \\
\hline $\begin{array}{l}\text { Xia et al, } \\
2020 \\
{[10]}\end{array}$ & $\begin{array}{c}\text { Prospective } \\
\text { interventional case } \\
\text { series study, } \\
\text { Zhejiang China } \\
\end{array}$ & N.A. & $\begin{array}{c}\mathrm{n}=30 \\
\mathrm{NCP} \\
\text { positive } \\
\text { (mean age } 54.5 \mathrm{yrs} \text { ) }\end{array}$ & $\begin{array}{l}\text { Conjunctivitis } \\
\mathrm{n}=1\end{array}$ & N.A. & $\begin{array}{c}\mathrm{n}=1 \text { and tear } \\
\text { positive } \\
\text { with conjunctivitis }\end{array}$ \\
\hline $\begin{array}{l}\text { Dai } \\
2020 \\
{[49]}\end{array}$ & $\begin{array}{l}\text { Case report, } \\
\text { (Pekin?!) } \\
\text { Beijing, China }\end{array}$ & N.A. & $\begin{array}{l}\mathrm{n}=1 \\
\text { a member of the } \\
\text { national expert panel on } \\
\text { pneumonia in Wuhan }\end{array}$ & Conjunctival congestion & $\begin{array}{c}\text { first to } \\
\text { COVID-19 }\end{array}$ & N.A. \\
\hline
\end{tabular}

NCP - Novel coronavirus pneumonia; DM - Diabetes mellitus; CHD - Coronary Heart Disease; COPD - Chronic Obstructive Pulmonary Disease; N.A. - not applicable. 
seems unlikely, but for those with a severe condition it may be justified.

Liang et al. discovered that the viral load of conjunctival sac secretion was directly proportional to the severity of the disease [19]. Wu et al. noted an interesting relationship between conjunctivitis and severity of COVID-19 and blood parameters [43]. They reported that patients with ocular symptoms were more likely to have higher white blood cell and neutrophil counts, and higher levels of procalcitonin, C-reactive protein, and lactate dehydrogenase than patients without ocular symptoms. Their investigation suggests that ocular abnormalities may occur among patients with more severe systemic manifestations or abnormal findings in blood tests. Finally, they suggest that ocular symptoms commonly appear in patients with severe pneumonia [30]. Xu et al., however, did not confirm that hypothesis, but the severity of disease in their patients was relatively moderate [43]. Seah et al. concluded that transmission through tears, regardless of the phase of infection, is low. However, they did not exam conjunctival swab, only tear samples [9]. All tear samples showed negative results, even when nasopharyngeal swab samples were continually positive. In addition, Xia et al. did not detect viral RNA in the tear fluid and conjunctival secretions of the severe or common-type patients without conjunctivitis [10].

Despite the low incidence of virus in tear and conjunctiva samples, a risk of conjunctival tissue transmission cannot be excluded. A drop of saliva from infected patients can still cause infection of the medical staff by the conjunctival tissue and the nasolacrimal duct. Ophthalmologists, dentists, ENT specialists and anaesthesiologists are at greater risk of infection during routine activities due to close contact with an infected patient. Therefore, non-pharmaceutical interventions (NPI), hygiene recommendations and personal protective equipment (PPE), including goggles, are essential.

The WHO has provided guidance on personal protective equipment in infection prevention and control when COVID-19 is suspected. Eye protection (goggles) or facial protection (face mask) should be worn, and healthcare workers are advised against touching any mucosal membranes (eyes, nose or mouth) [44]. Likewise, national ophthalmological societies, including the Polish Ophthalmological Society, announced recommendation/guidelines on how to deal with an ophthalmic patient during the COVID-19 epidemic [45]. Basically, there are three-pronged strategies: protecting staff with appropriate PPE, preventing spread of the virus from patients, and re-arrangement of workflow to minimise exposure time and/or risk of cross-infections. In accordance with the Polish Ophthalmological Society, available forms of PPE include: disposable gowns, masks (surgical, FFP2, FFP3), face shields, goggles and gloves. Regular disinfection of the hands, slit lamp, and objects that have contact with patients by using disinfectants (70\% solution of ethyl alcohol, $0.1 \%$ sodium hypochlorite, $5 \%$ bleaching agent, hospital antiseptic viricidal agents) is recommended. Every piece of ophthalmic equipment should be disinfected before and after contact with every single patient (slit lamp, Goldmann applanation tonometer, three-mirror lens).

It is suggested a three-stage path of taking precautions during ophthalmic examination and performing ophthalmic procedures.
First level includes:

a) reduction of routine visits and optional procedures (excluding conditions with the risk of irreversible impairment of vision); postponing planned ophthalmic procedures; introduction of telemedicine consultancy services and electronic prescriptions;

b) introduction of an epidemiological questionnaire - the basic triage of patients:

1) contact with a person who has COVID-19 symptoms or infected with SARS-CoV-2;

2) staying in areas with a high percentage of infections during the last 14 days;

3) symptoms: body temperature $>38^{\circ} \mathrm{C}$, cough, shortness of breath;

c) cessation of procedures that produce aerosol, e.g. noncontact tonometry (air puff), endoscopic tear duct drainage, general anaesthesia; d) training for the medical personnel on how to minimize the risk of infection in the face of the pandemic.

\section{Second level includes:}

a) usage of slit-lamp barriers (breath shields), which decrease the risk of SARS-CoV-2 transmission by the air from the infectious patient;

b) frequent disinfections of hands and equipment in the ophthalmologist's room; c) measurements of body temperature, reporting to the employer shortness of breath, cough, fever, emesis, and diarrhoea.

Third level includes:

a) necessity to wear masks for medical staff and patients;

b) strict hand hygiene; c) usage of proper personal protective equipment (PPE) by the medical staff; d) keeping a minimum 1-metre distance between patients in the waiting room [44].

Every patient reporting to the ophthalmic clinic/hospital should have their body temperature measured and asked to complete a short epidemiological questionnaire. In cases where it is necessary to transfer a patient to an infectious disease hospital, the nearest facilities can be found at the following website: https://www.gov.pl/web/koronawirus/ lista-szpitali [44]. As for general ophthalmic outpatients, PPE, including disposable caps, surgical mask and gown, is highly recommended.

Hand washing, again, is extremely important as a method for preventing the transmission of any pathogenic agent from the fingers to the mucous membranes of the face. Patients and medical personnel should avoid touching their face, eyes, nose and mouth with unwashed hands. Clinicians dealing with aerosol-generating procedures, such as endotracheal intubation and diagnostic testing using bronchoscopy, should additionally use airborne precautions, including N95 respirators or equivalent face masks and face shields or goggles for eye protection. Any urgent consultations (penetrating ocular injury, acute glaucoma, and alkali chemical injury, etc.) should be performed with appropriate PPE, whereas non-urgent cross-specialty consultations for in-patients should be referred to an outpatient setting after discharge.

There is also no evidence to suggest that healthy people wearing contact lenses (CL) should stop wearing CL because of an increased risk of developing COVID-19 [50]. Wearing 
prescription spectacles does not provide a proven protection against SARS-CoV-2. Patients should avoid touching their faces with unwashed hands and avoid wearing CL altogether when they are unwell (particularly with any cold or flulike symptoms). Patients must be reminded of the need to dispose of daily disposable lenses upon removal, the need for appropriate disinfection with reusable lenses, including the use of a rub-and rinse step where indicated, and appropriate case cleaning and replacement [50].

\section{CONCLUSIONS}

Although the incidence of SARS-CoV-2 in tear fluid and conjunctival tissue of patients with ocular symptoms and positive RT-PCR test is low, the possibility of infection by eye contact or tear fluid should be considered. The hygiene regime for all people and additional PPE for medical staff are mandatory. According to Wan et al., during the SARS-CoV outbreaks, no ophthalmologist involved in the care of these patients was infected, due to their standard use of PPE [46]. It is known, that during a pandemic, the majority of people do not want to attend clinics and hospitals [46]. It seems that interaction between doctors and patients through the Internet and artificial intelligence will become more and more important in the future. Preparations should be made as soon as possible. It is crucial to learn as much as possible during this pandemic to allow us to obtain the skills needed to deal with eventual upcoming threats.

\section{REFERENCES}

1. American Academy of Ophthalmology Coronavirus eye safety. 2020 https://www.aao.org/eye-health/tips-prevention/coronavirus-covid19eye-infection-pinkeye (access: 2020.04.22)

2. The Lancet Editorial Board. COVID-19: protecting health-care workers. Lancet. 2020; 395(10228): 922.

3. Zhu N, Zhang D, Wang W, et al. A novel coronavirus from patients with pneumonia in China 2019. N Engl J Med. 2020; 382: 727-733.

4. CDC, WHO Important coronavirus updates for ophthalmologists https://www.aao.org/headline/alert-important-coronavirus-context (access 27April 2020)

5. Lu J, Cui J, Qian Z, Wang Y, Zhang H, Duan Y, et al. On the origin and continuing evolution of SARS-CoV-2, National Science Review In press (2020), doi: 10.1093/nsr/nwaa036 (access: 2020.04.26)

6. Habibzadeh P, Stoneman EK The Novel Coronavirus: A Bird's Eye View, Int J Occup Environ Med. 2020; 11(2): 65-71.

7. Wu D, Wu T, Liu Q, Yang Z. The SARS-CoV-2 outbreak: what we know. Int J Infect Dis. 2020. https://www.sciencedirect.com/science/article/ pii/S1201971220301235 (access: 2020.04.27)

8. Yu A, Tu R, Shao X, Pan A, Zhou K, Huang J. A comprehensive Chinese experience against SARS-CoV-2 in ophthalmology. Eye and Vis. 2020; 7: 19 (doi.org/10.1186/s40662-020-00187-2) (access: 2020.04.26)

9. Seah I, Agrawal R. Can the Coronavirus Disease 2019 (COVID-19) Affect the Eyes? A Review of Coronaviruses and Ocular Implications in Humans and Animals. Ocul Immunol Inflamm. 2020; 1-5.

10. Xia J, Tong J, Liu M, Shen Y, Guo D. Evaluation of coronavirus in tears and conjunctival secretions of patients with SARS-CoV-2 infection. J Med Virol. In press; 2020.

11. Jun I, Anderson DE, Kang AE, Wang LF, Rao P, Young BE, et al. Assessing Viral Shedding and Infectivity of Tears in Coronavirus Disease 2019 (COVID-19) Patients. Ophthalmology In press; 2020.

12. Guan WJ, Ni ZY, Hu Y, Liang WH, Ou CQ, He JX, et al. China Medical Treatment Expert Group for Clinical Characteristics of Coronavirus Disease 2019 in China. N Engl J Med. In press; 2020.

13. Rothe C, Schunk M, Sothmann P, Bretzel G, Froeschl G, Wallrauch C, et al. Transmission of 2019-nCoV Infection from an Asymptomatic Contact in Germany. N Engl J Med. 2020 Mar 5; 382(10): 970-971 (doi: 10.1056/NEJMc2001468)
14. Romano MR, Montericcio A, Montalbano C, Raimondi R, Allegrini D, Ricciardelli G, et al. Facing COVID-19 in Ophthalmology Department, Current Eye Res. 2020. DOI: 10.1080/02713683.2020.1752737 (access: 2020.04.27)

15. Bonn D SARS virus in tears? Lancet Infect Dis. 2004; 4(8): 480.

16. Chan WM, Yuen KS, Fan DS, Lam DS, Chan PK, Sung JJ. Tears and conjunctival scrapings for coronavirus in patients with SARS, Br J Ophthalmol. 2004; 88(7): 968-969.

17. Loon SC, Teoh SC, Oon LL, Se-Thoe SY, Ling AE, Leo YS, et al. The severe acute respiratory syndrome coronavirus in tears. $\mathrm{Br} \mathrm{J}$ Ophthalmol. 2004; 88(7): 861-863.

18. America Academy of Ophthalmology, Alert: Important coronavirus updates for ophthalmologists, AAO Alerts, (2020) (access:2020.04.22)

19. Liang L, Wu P. There may be virus in conjunctival secretion of patients with COVID-19. Acta Ophthalmol. 2020; published online March 18. DOI: $10.1111 /$ aos.14413

20. Zhou P, Yang XL, Wang XG, Hu B, Zhang L, et al. A pneumonia outbreak associated with a new coronavirus of probable bat origin. Nature. 2020 Mar; 579(7798): 270-273. DOI: 10.1038/s41586-020-2012-7

21. Adhikari SP, Meng S, Wu YJ, Mao YP, Ye RX, Wang QZ, et al. Epidemiology, causes, clinical manifestation anddiagnosis, prevention and control of coronavirus disease (COVID-19) during the early outbreak period: a scoping review. Infect Dis Poverty 2020; 9(1): 29.

22. Rothan HA, Byrareddy SN. The epidemiology and pathogenesis of coronavirus disease (COVID-19) outbreak. J Autoimmun. In press; 2020: 102433.

23. Warnes SL, Little ZR, Keevil CW. Human Coronavirus 229E Remains Infectious on Common Touch Surface Materials, mBio 2015; 6(6): e01697-15.

24. Ikonen N, Savolainen-Kopra C, Enstone JE, Kulmala I, Pasanen P, Salmela A, et al. Deposition of respiratory virus pathogens on frequently touched surfaces at airports. BMC Infect Dis. 2018; 18(1): 437.

25. Kampf G, Todt D, Pfaender S, Steinmann E. Persistence of coronaviruses oninanimate surfaces and their inactivation with biocidal agents. J Hosp Infect. 2020; 104(3): 246-251

26. Ong SWX, Tan YK, Chia PY, et al. Air, Surface Environmental, and Personal Protective Equipment Contamination by Severe Acute Respiratory Syndrome Coronavirus 2 (SARS-CoV-2) From a Symptomatic Patient. JAMA. Published online March 04, 2020. (doi:10.1001/jama.2020.3227)

27. Sun C, Wang Y, Liu G, Liu Z. Role of the Eye in Transmitting Human Coronavirus: What We Know and What We Do Not Know. Preprints 2020, 2020030271 (doi: 10.20944/preprints202003.0271.v1)

28. Cheng-wei L, Xiu-fen L, Zhi-fang J. 2019-nCoV transmission through the ocular surface must not be ignored. The Lancet 2020; 395(10224): e39 (doi.org/10.1016/S0140-6736(20)30313-5)

29. Chen L, Deng C, Chen X, et al. Ocular manifestations and clinical characteristics of 534 cases of COVID19 in China: A cross-sectional study. medRxiv 2020 (doi.org/10.1101/2020.03.12.20034678)

30. Wu P, Duan F, Luo C, et al. Characteristics of ocular findings of patients with coronavirus disease 2019(COVID-19) in Hubei province, China. JAMA Ophthalmol. Published online March31, 2020. doi:10.1001/ jamaophthalmol.2020.1294

31. Bhattacharyya A, Sarma P, Sarma B, et al. Bacteriological pattern and their correlation with complications in culture positive cases of acute bacterial conjunctivitis in a tertiary care hospital of upper Assam. Medicine (Baltimore) 2020; 99. (DOI:10.1097/MD.0000000000018570.)

32. Prajapat M, Sarma P, Shekhar N, Avti P, Sinha S, Kaur H, et al. Drug targets for corona virus: A systematic review. Indian J Pharmacol. 2020; 52: 56-65.

33. Wan Y, Shang J, Graham R, et al. Receptor recognition by novel coronavirus from Wuhan: An analysis based on decade-long structural studies of SARS. J Virol. 2020.

34. Wagner J, Jan Danser AH, Derkx FH, et al. Demonstration of renin mRNA, angiotensinogen mRNA, and angiotensin converting enzyme mRNA expression in the human eye: evidence for an intraocular reninangiotensin system. Br J Ophthalmol. 1996; 80: 159-63.

35. Savaskan E, Löffler KU, Meier F, Müller-Spahn F, Flammer J, Meyer P. Immunohistochemical localization of angiotensin-converting enzyme, angiotensin II and AT1 receptor in human ocular tissues. Ophthalmic Res. 2004; 36: 312-20.

36. Holappa M, Valjakka J, Vaajanen A. Angiotensin(1-7) and ACE2, "The Hot Spots" of Renin-Angiotensin System, Detected in the Human Aqueous Humor. Open Ophthalmol J. 2015; 9: 28-32.

37. Määttä M, Tervahartiala T, Kaarniranta K, Tang Y, Yan L, Tuukkanen J, et al. Immunolocalization of EMMPRIN (Cd147) in the Human Eye 
and Detection of Soluble Form of EMMPRIN in Ocular Fluids. Current Eye Res. 2006; 31: 917-24.

38. Smith VJ, Dyrynda EA Antimicrobial proteins: From old proteins, new tricks. Mol Immunol. 2015; 68(2 Pt B): 383-398.

39. Malaczewska J, Kaczorek-Lukowska E, Wojcik R, Siwicki AK. Antiviral effects of nisin, lysozyme, lactoferrin and their mixtures against bovine viral diarrhoea virus. BMC Vet Res. 2019; 15(1): 318.

40. Flanagan JL, Willcox MD. Role of lactoferrin in the tear film. Biochimie 2009; 91(1): 35-43.

41. Colavita F, Lapa D, Carletti F, Lalle E, Bordi L, Marsella P, et al. SARSCoV-2 Isolation From Ocular Secretions of a Patient With COVID-19 in Italy With Prolonged Viral RNA Detection Ann Intern Med. 2020; [Epub ahead of print 17 April 2020]. doi: https://doi.org/10.7326/M201176 (access: 2020.04.27)

42. Lin C, Ye R, Xia YL. A meta-analysis to evaluate the effectiveness of real time PCR for diagnosing novel coronavirus infections. Genet Mol Res. 2015; 14(4): 15634-15641. https://doi.org/10.4238/2015 (access:2020.04.22)

43. Xu L, Zhang, X,Song W, Sun B, Mu J, Wang B, Wang Z, Cao Y, Dong X. Conjunctival polymerase chain reaction-tests of 2019 novel coronavirus in patients in Shenyang, China. doi: https://doi. org/10.1101/2020.02.23.20024935 (access:2020.04.24)
44. World Health Organization. Infection prevention and control during health care when novel coronavirus ( $\mathrm{nCoV}$ ) infection is suspected. Interim guidance, 2020.

45. Acta Ophthalmologica Polonica 2020; 122,1: 11-13, doi: https://doi. org/10.5114/ko.2020.94206 (access:2020.04.22)

46. Wan KH, Huang SS, Young A, Lam DSC. Precautionary measures needed for ophthalmologists during pandemic of the coronavirus disease 2019 (COVID-19), doi: 10.1111/aos.14438 (access:2020.04.26)

47. Zhang X, Chen X, Chen L, Deng C, Zou X, Liu W, et al. The infection evidence of SARS-COV-2 in ocular Surface:a single-center crosssectional study. Preprints from med Rxiv and bioRxiv. doi: https://doi. org/10.1101/2020.02.26.20027938 (access:2020.04.22)

48. Deng C, Yang Y, Chen H, et al. Ocular Dectection of SARS-CoV-2 in 114 Cases of COVID-19 Pneumonia in Wuhan, China: An Observational Study. Rochester, NY: Social Science Research Network, 2020 https:// papers.ssrn.com/abstract=3543587 (access: 2020.04 .22 )

49. Dai X. Peking University Hospital Wang Guangfa disclosed treatment status on Weibo and suspected infection without wearing goggles. Jan 22, 2020. http://www.bjnews.com.cn/news/2020/01/23/678189.html (access:2020.04.24)

50. Jones L, Walsh K, Willcox M, Morgan P, Nichols J. The COVID-19 pandemic: Important considerations for contact lens practitioners. Contact Lens and Anterior Eye, https://doi.org/10.1016/j.clae.2020.03.012 (access: 2020.04.22) 